\section{John Wales MD FRCP}

16.10.1937-07.08.2017

John Wales, founding Father and first Chairman of $A B C D$, has died suddenly while on holiday at the age of 79 years. The Association would not have arisen, nor achieved its subsequent success, but for his singular vision, drive and persuasion. His family fondly record that his 'strong-willed and determined' character was established soon in life, with a parental ethos encouraging debate and discussion, particularly on matters of medical history, usually conducted over the dining table.

Born in Scunthorpe, the middle of three brothers, and following the family relocation to Burnley, Lancashire, John's early formative education was received at the local grammar school, where his many gifted qualities were soon apparent academically, on the sporting field (particularly tennis and cricket) and in the music department, anticipating a very special future achievement of excellence.

With all three brothers a medical career clearly beckoned, and John duly proceeded to the School of Medicine, University of Leeds, winning several named prizes and gaining a sporting Half Blue. He qualified with distinction in 1960 .

As to be expected for the brightest student of the year, his first House appointments were with the Professorial Surgical and Medical (Professor Sir Ronald Tunbridge) Units at the General Infirmary Leeds, where he was subsequently to return for the major part of his professional career. On two occasions John ventured across the north-south divide, holding appointments, firstly as House Physician then as Registrar with the highly regarded Department of Endocrinology at the Hammersmith Hospital, London, but Leeds always remained his Alma Mater.

In 1965 he was awarded an MD for a thesis entitled "Studies on the hyperglycaemic activity of benzothiadiazine diuretics". It is evident that, by this time, John was steering towards a long-term specialist interest in diabetes, which in terms of future scientific papers and publications was to prove exceptionally productive.

His extensive bibliography over the next 40 years exhibits an impressive research enquiry, from fundamental experiments on a range of metabolic disorders, as well as studies of a more direct clinical nature. Perusing through the list of his publications, an eclectic perspective stands out with, for example, such diverse topics as "The effect of chlorpropamide on water transport across the toad bladder" (1971), "The prevalence of pathogenic yeasts and humoral antibodies to Candida in diabetic patients" (1978), "Urine dopamine in starving obese subjects" (1986); contrasting with clinical observations such as "Improved results for diabetic pregnancies after pre-pregnancy counselling" (1986) and "Diabetic diets and nutritional recommendations: what happens in real life" (1992) to name but a few from the very many articles that he published.

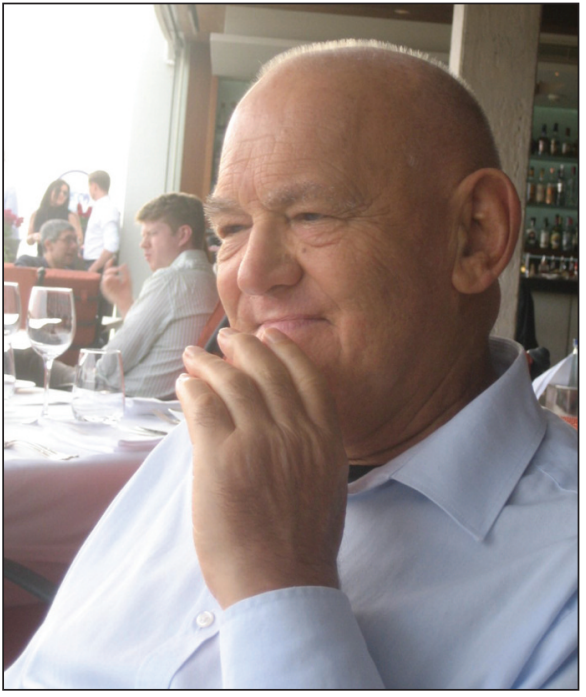

Appointed Honorary Consultant Physician to United Leeds Hospitals in 1971 and then Senior Lecturer in Medicine, for the next 30 years John held a succession of distinguished academic and administrative positions, both locally and at national level. As the Royal College Regional Advisor for Yorkshire, he delivered a strong voice supporting specialist clinical medicine and promoting higher medical training for junior doctors. Remarkably, his indomitable energy and enthusiasm led him to several prestigious professional challenges abroad which included a term as Assistant Professor of Medicine at the George Washington University School of Medicine, USA (1965-1967) and later as the Foundation Professor and Chairman of the Department of Medicine, United Arab Emirates (1989-1991). After retirement from the NHS, he accepted a most stimulating invitation as Visiting Consultant Diabetologist and Lecturer to the Beijing Chaoyang Diabetes Hospital, China (20052006).

But we hold John Wales in special regard as the driving force behind the formation of $A B C D$. Together with a small but growing number of consultant colleagues, he foresaw the need for a more appropriate forum to be established for specialist diabetologists to meet and discuss recent advances in diabetes care and matters pertaining to their clinical services. The focus would be primarily within the secondary care setting, whilst recognising the need for close cooperation with all members of the multidisciplinary teams both in primary care and the community. We also felt that there was an urgent need for diabetologists to have a more effective medicopolitical voice at a time of scarce and diminishing NHS resources. Diabetes was not then on politicians' and managers' lists of 
priorities and there was a prevailing misconception that most - if not all - of it could and should be dealt with in primary care. As a result, resources were steadily draining away from many wellestablished and well-recognised specialist units.

Above all, we believed that our role was to strive to ensure that the highest standards of care were provided for the many people living with diabetes. We were both privileged to have joined John with the beginning of this pioneering pursuit and were intrigued to be referred to as the 'Gang of Three', a reference to the 'Gang of Four' who founded the Social Democratic Party (SDP). It was John who then actually launched the association by organising the very first meeting in 1997 at the Royal College of Physicians. This was attended by a substantial number of very supportive consultants from all over the UK, and it was clear that we were on our way. By the autumn of that year, with our first formal meeting held in Windsor, it was apparent that a gathering momentum was taking place and that an important need was indeed being met. Now, 20 years later, the success of $A B C D$ in all its different domains is entirely apparent. Like the ill-fated SDP, we were not fully confident initially of such sustained success. It is largely thanks to John Wales that, unlike the SDP, ABCD has not only survived but has developed into an important and effective organisation.

Despite our awareness of John's undoubted attributes, he always expressed himself with utmost modesty, exemplified by his strict instruction that no eulogy should be given at his funeral and memorial service. But, subsequently, we have gained some insight into his remarkable private life with his loving family, living within the most idyllic village community of Acaster Selby. It was there that we learnt more of his exceptional musical talents. Shortly after retirement in 2002, John and his wife Barbara moved to Budapest, renting a flat in the city centre for a year, so that John could study composition under the Conservatoire maestro, Balázs Horváth. John's younger brother Chris recalls his astonishing subsequent productivity with a steady stream of compositions, including a string quartet, a sonata for clarinet and piano, a rhapsody for violin and piano, and most recently a song cycle entitled "Man and Nature".

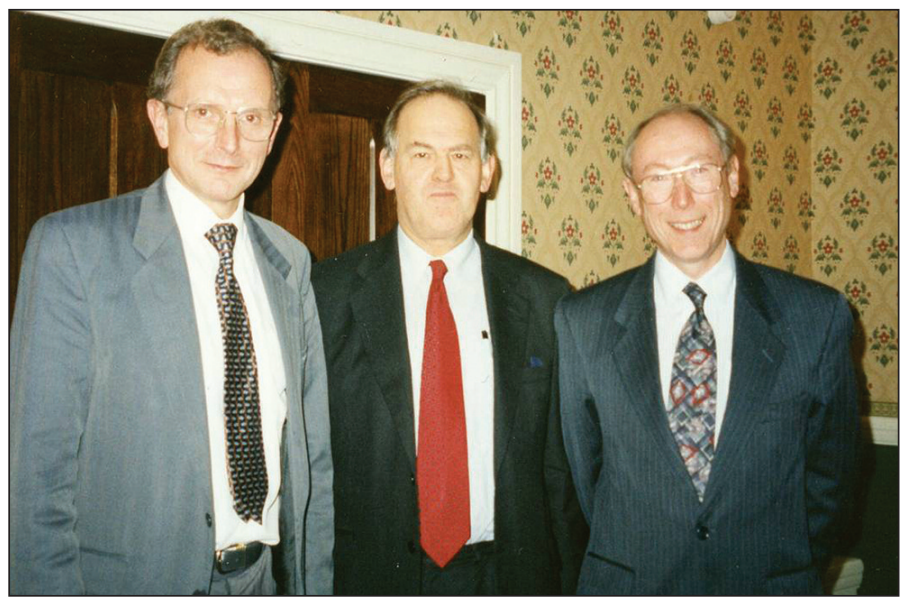

The 'Gang of Three':1st ABCD meeting, Windsor, October 1997 (centre, John Wales; left, Richard Greenwood; right, Ken Shaw)

For almost three decades he was organist at the village church, within a hundred yards of his family home and where he is now buried.

We send our genuine condolences to John's wife, Barbara, held in much affection by $A B C D$; and to his children Adam and Lucy who, at the service of celebration of his life, each read a poem special to John, one of which "A prayer in Spring" by Robert Frost which he himself had set to music for piano and alto voice.

John contributed so much in so many different ways, and we will very much miss his wise counsel and encouragement. $A B C D$ is now firmly established, a fitting testimony to the enduring legacy he leaves.

Ken Shaw

Richard Greenwood

October 2017

https://doi.org/10.15277/bjd.2017.153 Br J Diabetes 2017:17:165-166 